\title{
Benign Tracheal Neoplasm
}

National Cancer Institute

\section{Source}

National Cancer Institute. Benign Tracheal Neoplasm. NCI Thesaurus. Code C3602.

A non-metastasizing neoplasm that arises from the trachea. 